УДК 619.614.48

(C) 2012

Палій А. П., кандидат ветеринарних наук,

Завгородній А. І., доктор ветеринарних наук, член-кореспондент НААНУ

Дегтярьов І. М., кандидат ветеринарних наук

Національний науковий центр «Інститут експериментальної і клінічної ветеринарної медицини»

\title{
ФІЗИКО-ХІМІЧНІ ВЛАСТИВОСТІ ДЕЗІНФЕКТАНТУ «ДЗПТ-2»
}

\section{Рецензент - доктор ветеринарних наук Н. П. Чечоткіна}

\begin{abstract}
Наведені результати визначення фізико-хімічних властивостей нового дезінфікуючого препарату «ДЗПТ-2». Встановлено, щчо даний дезінфікуючий препарат має менший поверхневий натяг, ніж вода, й проявляє незначну корозійну активність на зразки сталі СТ3, сталі нержавіючої X25T, сталі оиинкованої листової, алюмінію АД1М, дюралюмінію Д1, латуні Л80, міді М1 порівняно з препаратом-еталоном (3 \% лужний розчин формальдегі-

ду) й може застосовуватися для санітарної обробки металевих конструкиій та обладнання тваринницьких приміщень.
\end{abstract}

Ключові слова: дезінфектант «ДЗПТ-2», поверхневий натяг, $р$, корозія, сталь, алюміній, дюралюміній, латунь, мідь.

Постановка проблеми. Застосування розчинів дезінфікуючих і мийно-дезінфікуючих препаратів для профілактичної та вимушеної дезінфекції об'єктів ветеринарного нагляду сприяє виникненню корозії металевих елементів, з яких складається обладнання. У зв'язку з цим необхідним є ретельний підбір засобів санації з урахуванням здатності металу протидіяти хімічному чиннику в конкретних умовах.

Аналіз основних досліджень і публікацій, у яких започатковано розв'язання проблеми. Процес корозії металевих конструкцій та обладнання проходить під впливом хімічного й електрохімічного впливу навколишнього середовища, що викликає зміну складу металу і його властивості, а іноді корозійні процеси перебігають із розпадом структурних складових, зміною фізико-механічних властивостей металів і сплавів. Застосування агресивних хімічних засобів для дезінфекції обладнання і металевих конструкцій збільшує можливість корозії металів, що зумовлює необхідність вивчення фізико-хімічних властивостей (pH, поверхневий натяг, корозійність) нових розроблених препаратів [1].

Встановлено, що препарат на основі ПГМГГХ у робочих концентраціях володіє низькою корозійною активністю щодо алюмінію, сталі
СТ3 та сталі оцинкованої [5]. Препарати на основі четвертинних амонієвих сполук не спричиняють суттєвої корозійної дії на метали в порівнянні з хлорорганічними засобами $[6,7]$. Вивчено корозійні властивості дезінфікуючих препаратів на основі перекису водню [2, 9]. Дослідженнями встановлено, що препарати, до складу яких входять поверхнево-активні речовини, володіють задовільними змочувальними властивостями та низькою корозією [4]. Слід також враховувати, що застосування деяких дезінфікуючих технологій негативно впливає на фізикомеханічні властивості гумових виробів [3].

Отже, засоби, що не викликають корозії металів, мають для тваринницьких підприємств важливе значення як із господарської точки зору, так і з точки зору збереження якості продукції та здоров'я споживачів.

Мета роботи. Визначити $\mathrm{pH}$, поверхневий натяг розчинів та вивчити корозійні властивості дезінфікуючого препарату «ДЗПТ-2» відносно зразків основних металів, що застосовуються у тваринництві.

Матеріали і методи досліджень. Нами були проведені дослідження з вивчення корозійних властивостей дезінфікуючого препарату «ДЗПТ-2», розробленого співробітниками ННЦ «ІЕКВМ». Даний препарат рекомендовано застосовувати для профілактичної та вимушеної дезінфекції тваринницьких приміщень у разі захворювання на туберкульоз сільськогосподарських тварин [8].

Визначення концентрації водневих іонів (pH)

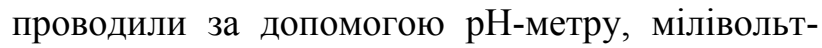
метру рН-121, ін. № 729.

Поверхневий натяг - сила, віднесена до одиниці довжини контуру, що обмежує поверхню розділу фаз, або робота, яку необхідно виконати, щоб збільшити вільну поверхню рідини за постійної температури на $1 \mathrm{~cm}^{2}$.

Визначення даного показника проводили у розчинів препарату «ДЗПТ-2» у концентрації 0,$5 ; 1 ; 1,5 ; 2 ; 2,5 \%$ за ДР за температури $20 \pm 0,5^{\circ} \mathrm{C}$. 
Зразки деззасобу поміщали в сталагмометр і підраховували кількість краплин, що витікали 3 прибору з заданою швидкістю. Визначення повторювали тричі й вираховували середній результат. Для порівняння застосовували бідистильовану воду.

Розрахунок показника поверхневого натягу розчинів «ДЗПТ-2» проводили за формулою:

$$
\mathrm{G}=\frac{\mathrm{N}_{1}-\mathrm{G}_{1}}{\mathrm{~N}_{0}},
$$

де:

$\mathrm{G}$ - поверхневий натяг досліджуваного розчину;

$\mathrm{G}_{1}$ - поверхневий натяг бідистильованої води;

$\mathrm{N}_{1}$ - число крапель бідистильованої води;

$\mathrm{N}_{0}$ - число крапель досліджуваного розчину.

Для визначення корозійної активності препаратів були визначені найбільш розповсюджені метали, що застосовуються під час будівництва та експлуатації тваринницьких приміщень: сталь СТ3; сталь нержавіюча X25T; сталь оцинкована листова; алюміній АД1М; дюралюміній Д1; латунь Л80; мідь М1.

Корозійну активність дезінфікуючого препарату визначали у концентрації $2 \%$ за ДР у порівнянні 3 препаратом-еталоном - $3 \%$ лужним розчином формальдегіду.

У ході проведення досліджень визначали наступні показники за формулами:

Втрата ваги: $\Delta \mathrm{m}=\mathrm{m}_{1}-\mathrm{m}_{2}$;

де:

$\Delta \mathrm{m}$ - різниця ваги зразків до і після дії препарату;

$\mathrm{m}_{1}$ - маса зразків до дії препарату;

$\mathrm{m}_{2}$ - маса зразків після дії препарату. де:

$\Delta \mathrm{m}$ - втрата ваги;

$\mathrm{s}$ - площа зразка металу, $\mathrm{m}^{2}$.

Ваговий показник: $\mathrm{K}_{2}=\Delta \mathrm{m} \times 10000 / \mathrm{T} \times \mathrm{s}$; де:

$\Delta \mathrm{m}$ - втрата ваги;

$\mathrm{T}$ - час дії препарату на метал;

$\mathrm{s}$ - площа зразка металу, $\mathrm{cm}^{2}$.

Відносна корозійна активність: $\mathrm{A}=\mathrm{K}_{\mathrm{e}} / \mathrm{K}_{\mathrm{n}}$; де:

$\mathrm{K}_{\mathrm{e}}$ - показник корозії препарату-еталону;

$\mathrm{K}_{\text {п }}$ - показник корозії досліджуваного препарату.

Результати досліджень. Препарат «ДЗПТ-2»це прозора рідина, від білого до жовтуватого кольору, зі специфічним запахом. При визначенні pH концентрату «ДЗПТ-2» встановлено, що його величина дорівнює $2,1 \pm 0,5$.

У результаті проведених досліджень із визначення поверхневого натягу робочих розчинів препарату були отримані результати, наведені в таблиці 1.

\section{1. Поверхневий натяг розчинів дезінфектанту «ДЗПТ-2»}

\begin{tabular}{|c|c|}
\hline Розчин препарату & Поверхневий натяг, \\
«ДЗПТ-2» & $10^{-3} \mathrm{H} / \mathrm{m}$ \\
\hline $0,5 \%$ за ДР & 52,14 \\
$1 \%$ за ДР & 51,85 \\
$1,5 \%$ за ДР & 51,49 \\
$2 \%$ за ДР & 50,87 \\
$2,5 \%$ за ДР & 50,20 \\
\hline Середнє значення & $51,31 \pm 0,35^{*}$ \\
\hline ВОДА & 72,75 \\
\hline
\end{tabular}

Примітка: *P=0,001

Зменшення ваги: $\mathrm{K}_{1}=\Delta \mathrm{m} / \mathrm{s}$;

\section{2. Корозійна активність дезінфектанту «ДЗПТ-2» (М士m)}

\begin{tabular}{|c|c|c|c|c|c|}
\hline \multirow{2}{*}{$\begin{array}{l}\text { Метал, } \\
\text { марка }\end{array}$} & \multicolumn{2}{|c|}{ Втрата ваги } & \multirow{2}{*}{$\begin{array}{c}\text { Зменшення ваги, } \\
\Gamma / \mathrm{m}^{2}\end{array}$} & \multirow{2}{*}{$\begin{array}{l}\text { Ваговий показ- } \\
\left.\text { ник, г/( }{ }^{2} \times \text { год. }\right)\end{array}$} & \multirow{2}{*}{$\begin{array}{l}\text { Відносна коро- } \\
\text { зійна активність }\end{array}$} \\
\hline & $\Gamma$ & $\%$ & & & \\
\hline $\begin{array}{l}\text { Сталь } \\
\text { СТ } 3\end{array}$ & $\begin{array}{c}0,0009 \\
\pm 0,00016\end{array}$ & 0,0169 & $\begin{array}{c}0,0133 \\
\pm 0,0018\end{array}$ & $\begin{array}{c}0,2305 \\
\pm 0,0179\end{array}$ & 12,3 \\
\hline $\begin{array}{c}\text { Сталь } \\
\text { нержавіюча X25T }\end{array}$ & $\begin{array}{c}0,0001 \\
\pm 0,00004\end{array}$ & 0,0105 & $\begin{array}{c}0,0050 \\
\pm 0,0011\end{array}$ & $\begin{array}{c}0,0772 \\
\pm 0,0094\end{array}$ & 28,1 \\
\hline $\begin{array}{c}\text { Сталь } \\
\text { оцинкована листова }\end{array}$ & $\begin{array}{c}0,0005 \\
\pm 0,00009 \\
\end{array}$ & 0,0339 & $\begin{array}{c}0,0066 \\
\pm 0,0012 \\
\end{array}$ & $\begin{array}{c}0,1075 \\
\pm 0,0168 \\
\end{array}$ & 22,0 \\
\hline $\begin{array}{c}\text { Алюміній } \\
\text { АД1М }\end{array}$ & $\begin{array}{c}0,0012 \\
\pm 0,00005\end{array}$ & 0,2846 & $\begin{array}{c}0,0159 \\
\pm 0,0019\end{array}$ & $\begin{array}{c}0,1311 \\
\pm 0,0218\end{array}$ & 367,8 \\
\hline $\begin{array}{l}\text { Дюралюміній } \\
\text { Д1 }\end{array}$ & $\begin{array}{c}0,0006 \\
\pm 0,00005\end{array}$ & 0,0623 & $\begin{array}{c}0,0103 \\
\pm 0,0028\end{array}$ & $\begin{array}{c}0,2985 \\
\pm 0,0419\end{array}$ & 538,5 \\
\hline $\begin{array}{c}\text { Латунь } \\
\text { Л80 }\end{array}$ & $\begin{array}{c}0,0004 \\
\pm 0,00003\end{array}$ & 0,0077 & $\begin{array}{c}0,0059 \\
\pm 0,0013\end{array}$ & $\begin{array}{c}0,0249 \\
\pm 0,0033\end{array}$ & 118,1 \\
\hline $\begin{array}{l}\text { Мідь } \\
\text { М1 }\end{array}$ & $\begin{array}{c}0,0008 \\
\pm 0,00004\end{array}$ & 0,0056 & $\begin{array}{c}0,0121 \\
\pm 0,0023\end{array}$ & $\begin{array}{c}0,0505 \\
\pm 0,0071\end{array}$ & 103,9 \\
\hline
\end{tabular}


У результаті аналізу отриманих даних, наведених у таблиці 1 , встановлено, що робочі розчини препарату «ДЗПТ-2» в концентрації 0,5$2,5 \%$ за ДР володіють кращою змочувальною здатністю, ніж вода.

Результати проведених досліджень із вивчення корозійних властивостей дезінфікуючого препарату «ДЗПТ-2» щодо основних зразків металів наведені в таблиці 2.

Дані таблиці 2 засвідчують, що препарат «ДЗПТ-2» на зразки сталі СТ3, нержавіючої Х25T, оцинкованої листової не чинить корозії, а втрата їх ваги, відповідно, у 12,3, 28,1 і 22,0 рази нижча від дії препарату-еталону. Втрата ваги зразків алюмінію АД1М і дюралюмінію Д1 у 367,8 і 538,5 рази відповідно нижча від дії еталону. Вага латуні Л80 і міді M1 зменшилась у

\section{БІБЛІОГРАФІЯ}

1. Алагезян Р. Г. Моющие и дезинфицирующие средства в молочной промышленности [Текст] / Р. Г. Алагезян. - М. : Лёгкая и пищевая промышленность, 1981. $-168 \mathrm{c}$.

2. Голов Е.А. Антимикробные и физикохимические свойства новых перекисных дезинфектантов [Текст]. Автореф. дис. ... канд. биол. наук : 03.00.07. - М., 2005. - 20 c.

3. Даниленко И. П. Изменение физико-механических свойств сосковой резины при паровой дезинфекции доильных аппаратов [Текст] / И. П. Даниленко // Тр. ВНИИВС - 1967. Т. XXVIII. - C. 96-99.

4. Кипин Е. Н. Ветеринарно-санитарная оценка и дезинфекция объектов мясоперерабатывающего предприятия бактерицидными пенами [Текст]. Автореф. дис. ... канд. вет. наук : 06.02.05. - М., 2011. - 23 c.

5. Коваленко В. Л. Фізико-хімічні властивості дезінфікуючого препарату на основі полігексаметиленгуанідин гідрохлориду [Текст] / В. Л. Коваленко
118,1 і 103,9 рази нижче, ніж після дії еталонного препарату.

\section{Висновки:}

1. Дезінфікуючий препарат «ДЗПТ-2» проявляє незначну корозійну активність відносно сталі СТ3, сталі нержавіючої X25T, сталі оцинкованої листової, алюмінію АД1М, дюралюмінію Д1, латуні Л80, міді M1, а показники, які характеризують його корозійну дію, є суттєво нижчими порівняно з дією препарату-еталону.

2. Робочі розчини препарату «ДЗПТ-2» володіють кращою змочувальною здатністю порівняно $з$ водою.

3. Дезінфікуючий препарат «ДЗПТ-2» можна застосовувати для дезінфекції тваринницьких приміщень і об'єктів ветеринарного нагляду.

[та ін.] // Ветеринарна біотехнологія. - К., 2011. - № 19. - C. $81-85$.

6. Кривохижа С. М. Корозійні властивості засобів для санітарної обробки молочного обладнання [Текст] / С. М. Кривохижа // Науковий вісник ЛНУВМБТ ім. С. 3. Гжицького. - 2008. - Т. 10, № 2(37). - Ч. 4. - С. 82-85.

7. Маклаков А. С. Бактерицидная активность и коррозионное действие дезинфицирующего препарата Смейк [Текст] / А. С. Маклаков // Ветеринария. -2007 . - № 1. - С. 39-41.

8. Патент на корисну модель № 29364 Україна, МПК А 61L 2/16. Дезінфікуючий засіб «ДЗПТ-2» / А. І. Завгородній [та ін.] - № u 2007 10324; заявл. 17.09.2007; опубл. 10.01.2008, Бюл. № 1.

9. Потапченко Н. Г. Изучение антимикробного действия пероксида водорода в присутствии различных металлов [Текст] / Н. Г. Потапченко [и др.] // Химия и технология воды. - 1994. № 2. - C. 203-209. 